\title{
FORMER AUDIT PARTNERS ON AUDIT COMMITTEES: IMPLICATIONS FOR RUSSIAN CORPORATE GOVERNANCE
}

\author{
Genevieve Scalan
}

Texas A \& M University - Kingsville, TX

\begin{abstract}
The Moscow Exchange in conjunction with the Organization for Economic Cooperation and Development (OECD) continues to address improvements in Russian corporate governance by conducting annual roundtables (OECD, 2017). My research relates to corporate governance provided by audit committees. I examine relationships between former audit partner (FAP) audit committee members and auditors, via a network similar to the interlocking directorate. Using a dataset of U.S. auditor dismissals, I construct unique network variables measuring the relational ties between FAP audit committees and auditors. I find some evidence suggesting ties created by former audit partners may increase auditor switching possibly indicating impaired auditor independence.

This outcome suggests implications for Russian corporate governance because it is likely Russian Boards of Directors would experience similar circumstances as their U.S. counterparts. As the Moscow Exchange continues its partnership with the OECD to improve corporate governance, audit quality and auditor independence should be considered in the dialogue.
\end{abstract}

Keywords: Corporate Governance, Audit Committee, Former Audit Partners.

DOI: http://dx.doi.org/10.15549/jeecar.v4i1.154

\section{INTRODUCTION}

Russia's corporate governance environment for Joint-Stock Companies experienced key events when the Bank of Russia approved the Russian Code of Corporate Governance (the Code) in 2014 (Bank of Russia, 2014) and registered the Listing Rules for the Moscow Stock Exchange (Listing Rules) in 2015 (Moscow Exchange, 2015). The Code and Listing Rules require Joint-Stock Companies to establish Boards of Directors with independent members and committees that include an audit committee. In their analysis of auditor independence in Russia, Sucher and Bychkova (2001) suggest auditor independence is key to financial statement credibility. The audit committee is responsible for dismissing, hiring, and communicating with the external auditors and it is recognized as a governance mechanism ensuring auditor independence (BRC, 1990). The U. S. Sarbanes Oxley Act of 2002 (SOX) is intended to foster auditor independence and require a completely independent audit committee for SEC registrants (United States Government Printing Office, 2002). Similarly, the Russian Code of Corporate Governance requires an audit committee be established with at least one independent board member for Joint-Stock Companies (Bank of Russia, 2014).

My research investigates the association of 
audit committee membership of former audit partners (FAP) with auditor dismissals. Directorates represent interlocking networks when a person affiliated with an organization is a member of the board of directors of another organization (Mizruchi, 1996). Among these interlocked directorates, I examine the audit committee networks that occur when audit committee members sit on the audit committees of multiple public companies engaging the same audit firms. My research examines the question: do increasing former audit partner (FAP) audit committee-auditor network ties decrease or increase the likelihood of switching auditors?

Using a set of U. S. clients dismissing auditors and a matched control sample of U.S. clients retaining their incumbent auditors during 2007, I analyze the effect of audit committee-auditor ties on auditor dismissals by estimating a logistic regression model for the likelihood of auditor dismissals and include the ties as explanatory variables. I find partial support that suggests that the presence of former audit partners (of an incumbent auditor) increases the likelihood of auditor dismissal.

\section{LITERATURE REVIEW AND HYPOTHESIS DEVELOPMENT}

The Russian Code of Corporate Governance places high importance on the audit committee as providing auditors with the independence required to fulfill their monitoring function (Bank of Russia, 2014). The audit committee is important to auditor independence in Russia per the Listing Rules (Moscow Exchange, 2015). Research on auditor independence shows additional factors are relevant in ensuring auditor independence. Iwasaki (2014) finds in Russia, overall board composition is important and auditor independence is achieved by contracting with foreign auditors, having foreign investors, and affiliation with a business group. Sucher and Bychkova (2010) suggest Anglo-American means of attaining auditor independence are not as useful in the context of a transitional economy. They posit social, cultural and economic conditions in transitional economies alter the feasibility of auditor independence.

Under the resource dependency theory of interlocking directorates, information is often primary among the variety of resources a board of directors may co-opt (Useem, 1984). The interlocking directorate and its connection to the audit market are examined in two extant studies: Davison, Stening, and Wai (1984) and Courtney and Jubb (2005). Davison, Stening, and Wai (1984) show there is a significant relationship between the number of director interlocks and the probability interlocked companies are audited by the same firm as the focal company. Courtney and Jubb (2005) find the interlocking directorate is associated with longer tenure after four years.

The demand side auditor switching literature investigates the effects of governance on switching and relies on the assumption that effective governance constrains auditor switching for opinion shopping purposes. For example, Carcello and Neal (2003) find greater audit committee independence and governance expertise contribute to shielding the auditor from dismissal following a going concern opinion modification. Chen and Zhou (2007) follow Arthur Andersen clients and find audit committee independence and expertise are factors in early dismissal of Arthur Andersen as information increased regarding the Enron scandal.

Research indicates using former auditors as employees, executives and directors affects organizational financial and audit outcomes at organizations. Menon and Williams (2004) examine organizations with a director or officer who was previously a partner at the accounting firm that audits the firm's current financial statements. They find clients with former audit partners as either an employee or a director have larger abnormal accruals than clients with no former audit partners. Lennox (2005) researches audit opinions for clients with executives who are former auditors, though not necessarily partners. He finds clients affiliated with their auditor through executives who are firm alumni are more likely to receive clean audit opinions. Lennox and Park (2007) examine former auditor affiliations and finds alumni, not necessarily partners, who are executives appear to influence auditor selection toward their former firms. This study also shows independent audit committees attenuate this effect. Naiker and Sharma (2009) conduct former audit partner research at the board of director level and find clients with alumni former audit partners disclose fewer internal control deficiencies.

There is no consensus on whether effects 
associated with former audit partners are the result of impaired independence arising from the influence of a former partner or if the effects stem from audit partner expertise. In other words, are fewer internal control deficiencies disclosed because the former partner is better able to hide them? On the other hand, are fewer deficiencies disclosed because the former audit partner is in a better position when negotiating with the auditor? Perhaps the former audit partner is better at executing her governance responsibilities thanks to her audit experience. Whether they are valued for special expertise or for special influence, it is reasonable to infer organizations recruit former audit partners to sit on audit committees because of their perceived efficacy in some form of objective attainment. This special knowledge or influence represents a relational asset which creates potential switching costs when the client dismisses the audit firm with which the alumni audit committee member was associated. I consider former audit partner ties to the auditor and their effect on the likelihood of switching auditors. My hypothesis, in alternate form, is:

H1: The likelihood an incumbent auditor will be dismissed decreases when an audit committee member is a former audit partner for the firm engaged by the client.

\section{METHODOLOGY OF THE RESEARCH}

My analysis concentrates on the effect of audit committee-auditor ties on auditor switching by clients with incumbent Big 4 auditors. In addition to FAP ties, I employ several variables, representing a hierarchy of audit committeeauditor ties. I hypothesize these ties will correlate with the likelihood of switching auditors. The model, as shown below, controls for audit committee characteristics, client financial characteristics, and client-auditor switching characteristics.

DISMISS $=\alpha+\beta_{1}$ (TieVariables) +
$\beta_{2}$ FAPTies $+\beta_{3}$ EngMostTied +
$\beta_{4}$ ACFinExpts $+\beta_{5}$ ACStockOwn +
$\beta_{6}$ ACSize $+\beta_{7}$ GC $+\beta_{8}$ ICMW +
$\beta_{9}$ Restatement $+\beta_{10}$ MngmtChng +
$\beta_{11}$ AUDTenure $+\beta_{12}$ AudIndExpt +
$\beta_{13}$ ModAltman $+\beta_{14}$ ROA $+\beta_{15}$ Loss $+\varepsilon$

Hypothesis 1 addresses the ties created by former audit partners sitting on audit committees; I create the variable, FAPTies, to test this hypothesis. This variable is coded 1 if there are any audit committee members who were former audit partners of the incumbent auditor.

Other forms of ties are likely to affect auditor engagements after dismissals. To test for and control for the effect of ties to the successor auditor, I employ a variable I name EngMostTied. I code the binary variable as 1 if the client engaged the auditor with the most ties for the 2007 engagement. The variable ChrACTiesThe is number of ties where the audit committee chair at the dismissing client is on the audit committee at the associated client and the dismissed auditor is also the auditor at the associated client. I use ACChrTies to mean the number of ties where an audit committee member at the dismissing client is the audit committee chair at the associated client and the dismissed auditor is also the auditor at the associated client. The variable ACACTies corresponds to the number of ties where an audit committee member at the dismissing client is on the audit committee at the associated client and the dismissed auditor is also the auditor at the associated client.

I include control variables to measure the audit committee attributes researchers find correlate with auditor switching. Audit committee financial expertise is associated with good governance as evidenced by reduced earnings management (Vefeas, 2005). I include a financial expertise variable, ACFinExpts, to capture the presence of financial experts on the audit committee. Evidence shows audit committee stock ownership aligns audit committee interests with those of the other shareholders: audit committee ownership decreases earnings surprises (Vefeas, 2005). I define the variable ACStockOwn as the percentage of a company's outstanding stock owned by the entire audit committee. Audit committee size is a board characteristic associated with governance effectiveness. Klein (2002) finds audit committee independence increases with audit committee size. Obviously, a larger committee offers the opportunity for more ties and I control for audit committee size. The variable ACSize is the number of members on the audit committee.

Client financial characteristics are associated with auditor switching and I control for them in addition to the audit committee characteristics. Deteriorating financial position is found to be associated with a higher likelihood of switching auditors (Shu, 2000). I develop my financial 
distress proxy, ModAltman, using Shumway's Modified Altman (2001) weights. In addition to a financial distress summary measure, switching models often control for return on total assets $(R O A)$ and I include this variable in my model. Because poor financial performance contributes to auditor switching (Schwartz and Menon, 1985), I predict client $R O A$ for fiscal year 2006 will be negatively associated with auditor switching. I also utilize a binary variable, Loss, where 1 signifies the client has a Net Operating Loss for year 2006, as an additional financial performance control. As Carcello and Neal (2003) and Landsman, Nelson, and Rountree (2009) find, I expect the Loss variable will have a positive coefficient and be significantly associated with dismissing auditors.

Prior research shows several variables are predictive of auditor switching and I include them in my model. These are: going concern modified opinion from the dismissed auditor (GC), at least one internal control material weakness (ICMW) cited in $10 \mathrm{~K}$, client management changes, auditor tenure, and auditor industry expertise. Chow and Rice (1982) find support for the contention that clients tend to switch auditors following receipt of a modified opinion. I include a variable, $G C$, which I code as 1 if the client received a going concern modification for financial statements filed for fiscal year 2006.

Clients dismiss auditors more frequently if auditors state the client has an ICMW report (Ettredge, Li, and Scholz, 2007). I predict ICMW will increase the likelihood of auditor switching. I construct the ICMW variable by coding as 1 any observation with an ICMW report in 2006. In 2013, Hennes, Leone, and Miller find auditor turnover is higher for restating clients than for non- restating clients. I search for restatements in both 2006 and 2007 for the clients in this study. I code the variable RESTATEMENT as a 1 if the client restated the financials for any reason in either 2006 or 2007.

When clients change management, they frequently change auditor relationships (Schwartz and Menon, 1985). My management change variable, MngmtChng, is coded 1 in the presence of a management change in an observation. I define presence of a management change as being the hiring of a new CEO or CFO or both in either calendar year 2006 or 2007.

I employ two variables related to auditors' relationships with clients which researchers typically include in auditor switching studies. Auditor tenure and auditor industry expertise are associated with decreasing the likelihood of changing auditors. Carcello and Neal (2003) as well as Blouin, Grein, and Rountree (2007) control for tenure in their auditor switch studies. Landsman, Nelson, and Rountree (2009) find tenure is still negatively associated with auditor switches although the effect is slightly lower in the post Enron era. Following extant switch literature, I include the variable AudTenure in my model. AudTenure is the number of years the dismissed auditor, or the incumbent auditor for non-dismissing observations has served on the engagement, truncated at seven years.

I follow Hogan and Jeter (1999) and select client assets for my market share proxy. If the engaged auditor or the incumbent auditor for non-dismissing control observations audits the most client assets in an industry, the AudIndExpt variable is coded 1 for switched to industry expert. I define industry by 2 digit SIC code.

I draw the sample for this study from the population of U.S. publicly registered companies engaging new audit firms during calendar year 2007. I use the AuditAnalytics Auditor Changes Data Set to obtain 1,636 observations constituting all client-audit firm realignments for 2007. From this set, I select the 425 clients with Big 4 predecessor auditors. In order to suppress supply side effects, I eliminate 80 observations from the sample because the auditor resigned from the engagement; I retain the cases when the client dismisses the auditor. I further reduce the sample by removing any client with an SIC code indicating it is a financial institution, fund or REIT. I am unable to find sufficient financial information for 97 clients and I delete them from the sample. The sample for which I seek matching observations contains 120 clients with Big 4 predecessor auditors dismissing the audit firm in 2007.

I use the Compustat North American Database to collect a matching, non-dismissing control observation for each of the dismissing clients. I cannot find acceptable matches for 31 of the dismissing clients and the final sample contains 178 observations of 89 dismissing clients and 89 non-dismissing matched clients. I match the dismissing client to the control client based on audit firm, size, and SIC code. The selected matches are the non-dismissing clients of the 
same auditor with assets within $30 \%$ of the dismissing client.

In gathering the audit committee biographical information, I refer to the Schedule 14A, Definitive Proxy Statement (DEF 14A), filed with the SEC with information about the audit committee members who dismiss the auditor. I gather data for the former audit partner variables, the audit committee financial expertise variables, and audit committee stock ownership from the DEF $14 \mathrm{~A}$ as well. I search the AuditAnalytics Database to obtain the Internal Control Material Weakness and Going Concern Modification variables. I employ AuditAnalytics in gathering information to determine which firms are the industry experts. Compustat supplies all financial variables used in my analysis.

\section{RESULTS}

Descriptive statistics show the big 4 auditor dismissals are evenly distributed with no one auditor being dismissed significantly more often than any other Big 4 auditor. The frequencies for the tie variables indicate the data set has fewer ties created by the audit committee chairs than by the other committee members.

In univariate tests, I examine differences between the sample of dismissing companies and the control companies using t-tests for continuous variables and a Wilcoxon Z-test for the dichotomous variables. The FAPTies variable has insufficient cases for the Wilcoxon and the test for this variable is the Fisher's Exact test. First, I test the tie variables; there are no significant differences between the dismissing observations and the matches. Next, I test the control variables and find several with significant differences between dismissing and non-dismissing clients. The Wilcoxon test for the variable measuring whether or not the client engaged the auditor with the most ties suggests EngMostTies is different for the two samples with a p-value of less than .10. The variables measuring presence of ICMW, management change, and use of industry expert are significantly different for the two populations at a less than $.01 \mathrm{p}$-value level. I retain these significantly different variables as well as the control variables without significant differences between the populations for my multivariate model. Finally, I examine two variables not in the model to validate my size match. Neither Total Assets nor Total Revenue has significant t-test statistics; the match is valid.

I test the Hypothesis by estimating a binomial logit model because my dependent variable takes the binary form of 1 for an auditor dismissal and 0 for no dismissal (Cohen, Cohen, West, and Aiken, 2003). First, I estimate the likelihood of dismissing the auditor using only the control variables in the model. Next, I add the ordinal audit committee/auditor tie variables to the group of control variables and re-estimate the model. I substitute each tie variable and estimate the model an additional five times; I tabulate the results in Table 1.

The model with only control variables fits with a likelihood ratio chi square of .0002 . The pseudo- $\mathrm{R}^{2}$ for the model with no tie variables is .1940. Consistent with the univariate tests, the significant control variables are: ICMW, MngmtChng, and AudIndExpt. I find a management change is associated with a higher likelihood of dismissal. Reported internal control material weakness is associated with auditor dismissal as is switching to an industry expert. The coefficient directionalities and significances hold across the additional five iterations of the model.

I re-estimate the model five times inserting one ordinal tie variable in place of the previous each time I rerun the model (Columns 2-6 of Table 1) while retaining the FAP tie. I find the Former Audit Partner Ties are positive and significant and other forms of ties to the auditors are not significant. All models have an adequate goodness of fit as shown by the likelihood chi square p-values. The former audit partner tie variable is positive and significant. The inference, these ties increase the likelihood of the incumbent being dismissed, should be made cautiously due to the small number of observations with cases of former audit partner ties. The FAPTies variable does increase the pseudo-R². 
Table 1. Logistic Regressions Ordinal Tie Variables

DISMISS $=\alpha+\beta_{1}$ (OrdinalTieVariables $)+\beta_{2}$ FAPTies $+\beta_{3}$ EngMostTied $\beta_{4}$ ACFinExpts + $\beta_{5}$ ACStockOwn $+\beta_{6}$ ACSize $+\beta_{7}$ GC $+\beta_{8}$ ICMW $+\beta_{9}$ Restatement $+\beta_{10}$ MngmtChng $+\beta_{11}$ AUDTenure + $\beta_{12}$ AudIndExpt $+\beta_{13}$ ModAltman $+\beta_{14}$ ROA $+\beta_{15}$ Loss $+\varepsilon$

\begin{tabular}{|c|c|c|c|c|c|c|c|}
\hline \multirow[b]{2}{*}{ Variable } & \multirow[b]{2}{*}{$\operatorname{Prd}^{\mathrm{a}}$} & \multicolumn{2}{|c|}{ Column 1} & \multicolumn{2}{|c|}{ Column 2} & \multicolumn{2}{|c|}{ Column 3} \\
\hline & & Coeff & $\mathrm{P}>X^{2 \mathrm{a}}$ & Coeff & $\operatorname{Pr}>X^{2 a}$ & Coeff & $\operatorname{Pr}>X^{2 \mathrm{a}}$ \\
\hline Constant & $?$ & -.454 & .666 & -.481 & .651 & -.479 & .653 \\
\hline \multicolumn{8}{|l|}{ Tie Variables } \\
\hline ChrChrTies & - & & & & & -.169 & .408 \\
\hline FAPties & - & & & 1.657 & $.080^{*}$ & 1.697 & $.078^{*}$ \\
\hline \multicolumn{8}{|l|}{ Control Variables } \\
\hline EngMostTied & $?$ & -.282 & .593 & -.2463 & .642 & -.231 & .665 \\
\hline ACFinExpts & $?$ & -.665 & .312 & -.638 & .333 & -.659 & .322 \\
\hline ACStockOwn & $?$ & -5.674 & .338 & -5.560 & .3463 & -5.493 & .349 \\
\hline ACSize & $?$ & .011 & .964 & -.026 & .912 & -.024 & .922 \\
\hline GC & + & -1.004 & .112 & -1.026 & .216 & -1.011 & .111 \\
\hline ICMW & + & .840 & $.040^{*}$ & .811 & $.047^{*}$ & .802 & $.050^{*}$ \\
\hline Restatement & + & -.0100 & .491 & .047 & .459 & .059 & .449 \\
\hline MngmtChng & + & 1.261 & $.000^{*}$ & 1.240 & $.000^{*}$ & 1.244 & $.000^{*}$ \\
\hline AudTenure & - & .0667 & .257 & .081 & .217 & .081 & .217 \\
\hline AudIndExpt & $?$ & -1.322 & .003 & -1.345 & .001 & -1.341 & .002 \\
\hline ModAltman & - & -.044 & .118 & -.045 & .113 & -.044 & .115 \\
\hline ROA & - & .980 & .250 & 1.008 & .239 & .997 & .241 \\
\hline Loss & + & .306 & .270 & .362 & .235 & .353 & .241 \\
\hline Pseudo $\mathrm{R}^{2}$ & & & .1940 & & .2052 & & .2054 \\
\hline LR P>Chi-Square & & & .0002 & & .0002 & & .0003 \\
\hline DOF & & & 13 & & 14 & & 15 \\
\hline $\mathrm{n}$ & & & 178 & & 178 & & 178 \\
\hline
\end{tabular}

$\mathrm{a}=$ the Wald $\chi 2$ is one-tail when coefficient directionality is predicted. The test is two-tail when not predicted. ${ }^{*}=\mathrm{p}<.10$. 
Table 1. (Continued) Logistic Regressions Ordinal Tie Variables

DISMISS $=\alpha+\beta_{1}$ (OrdinalTieVariables $)+\beta_{2}$ FAPTies $+\beta_{3}$ EngMostTied $\beta_{4}$ ACFinExpts + $\beta_{5}$ ACStockOwn $+\beta_{6}$ ACSize $+\beta_{7}$ GC $+\beta_{8}$ ICMW $+\beta_{9}$ Restatement $+\beta_{10}$ MngmtChng + $\beta_{11}$ AUDTenure $+\beta_{12}$ AudIndExpt $+\beta_{13}$ ModAltman $+\beta_{14}$ ROA $+\beta_{15}$ Loss $+\varepsilon$

\begin{tabular}{|c|c|c|c|c|c|c|c|}
\hline \multirow[b]{2}{*}{ Variable } & \multirow[b]{2}{*}{$\operatorname{Prd}^{\mathrm{a}}$} & \multicolumn{2}{|c|}{ Column 4} & \multicolumn{2}{|c|}{ Column 5} & \multicolumn{2}{|c|}{ Column 6} \\
\hline & & Coeff & $\operatorname{Pr}>X^{2 a}$ & Coeff & $\operatorname{Pr}>X^{2 a}$ & Coeff & $\operatorname{Pr}>X^{2 a}$ \\
\hline Constant & $?$ & -.460 & .666 & -.485 & .649 & -.433 & .689 \\
\hline \multicolumn{8}{|l|}{ Tie Variables } \\
\hline ChrACTies & - & .137 & .374 & & & & \\
\hline ACChrTies & - & & & -.023 & .482 & & \\
\hline ACACTies & - & & & & & .066 & .405 \\
\hline FAPties & - & 1.604 & $.087^{*}$ & 1.661 & $.080^{*}$ & 1.624 & $.084^{*}$ \\
\hline \multicolumn{8}{|l|}{ Control Variables } \\
\hline EngMostTied & $?$ & -.284 & .602 & -.243 & .651 & -.277 & .612 \\
\hline ACFinExpts & $?$ & -.621 & .348 & -.638 & .333 & -.633 & .337 \\
\hline ACStockOwn & $?$ & -5.569 & .349 & -5.54 & .348 & -5.629 & .342 \\
\hline ACSize & $?$ & -.037 & .878 & -.025 & .917 & -.043 & .862 \\
\hline GC & + & -1.065 & .103 & -1.023 & .109 & -1.050 & .105 \\
\hline ICMW & + & .817 & $.046^{*}$ & .811 & $.047^{*}$ & .805 & $.049^{*}$ \\
\hline Restatement & + & .032 & .472 & .049 & .457 & .039 & .466 \\
\hline Mngmt Chng & + & 1.233 & $.000^{*}$ & 1.241 & $.000^{*}$ & 1.234 & $.000^{*}$ \\
\hline AudTenure & - & .081 & .434 & .081 & .216 & .080 & .221 \\
\hline AudInd Expt & $?$ & -1.354 & .003 & -1.345 & .003 & -1.35 & .003 \\
\hline ModAltman & - & -.045 & .108 & -.045 & .117 & -.046 & .108 \\
\hline ROA & - & 1.036 & .233 & .998 & .244 & 1.061 & .229 \\
\hline Loss & + & .376 & .227 & .359 & .239 & .379 & .227 \\
\hline Pseudo $\mathrm{R}^{2}$ & & & .2057 & & .2052 & & .2055 \\
\hline LR P $>$ Chi-Square & & & .0003 & & .0003 & & .0003 \\
\hline DOF & & & 15 & & 15 & & 15 \\
\hline $\mathrm{n}$ & & & 178 & & 178 & & 178 \\
\hline
\end{tabular}

$\mathrm{a}=$ the Wald $\chi 2$ is one-tail when coefficient directionality is predicted. The test is two-tail when not predicted. ${ }^{*}=\mathrm{p}<.10$.

Audit committees vary in size and an audit committee member may sit on several additional boards of directors or she may be on no other boards. This means, for example, two audit committee ties can constitute 100 percent of a client's ties or a much smaller percentage and may represent a difference in switching costs. Giving up ties to an auditor constituting 100 percent of a client's ties could arguably represent higher switching costs than giving up ties that represent 20 percent of ties to all auditors. For sensitivity testing, I create a new 
tie ratio measure by dividing the ordinal tie count by the total number of ties the organization has to any auditor. The former audit partner tie variable remains positive and significant in all reiterations of the model. In an additional sensitivity test, I re-specify the control tie variables in 4 additional forms. I find FAP ties remains significant with the addition of ChrBODTies, ACBODTies, BinaryACChr, and BinaryACA. The control variables are stable in all iterations of the model, retaining their coefficient directionalities and significances.

It is possible that the Former Audit Partner ties represent a conduit for negative information about the potential quality of an incumbent auditor. In turn, this would lead to a higher likelihood of auditor dismissal as found in this study. Similarly, it is plausible that alternative sources of bad news would be available to the clients in my sample. My data set is comprised of clients who dismissed Big 4 auditors. To confirm there is no contagion, I investigate auditor changes for the matched set of clients in the year immediately before and after the year of my study and find clients do not dismiss any particular firm in a way that establishes a pattern of contagion. For the set of 178 clients, 4 changed auditors in 2006 and 12 changed auditors in 2008. Of these changes, 14 were from Big 4 auditors and two were from smaller auditors. The distribution of the auditor switches does not indicate a pattern; of the 12 clients who left Big 4 auditors, two clients switched from KPMG, two stopped using Ernst and Young, five switched from Deloitte, and five clients left PWC. If some dismissal causing event related to one of the auditors occurred in 2007, I would expect to see a larger number of dismissals for that auditor. For the 89 dismissing clients in 2007, 20 dismissed PWC, 22 dismissed E\&Y, 24 dismissed Deloitte, and 23 dismissed KPMG. This even distribution does not imply negative information specific to one auditor.

\section{CONCLUSION}

I seek to add to the ongoing corporate governance dialogue for Russia by examining the potential impact of audit committee-auditor network ties on switching costs and the concomitant likelihood of auditor dismissals. I test for the significance of former audit partner ties in my dismissal models. My findings suggest former audit partner ties may increase auditor dismissals. Future OECD-Moscow Exchange roundtables may wish to include discussion of how to modify audit committee membership to consider auditor independence. My findings are limited by the inability to observe those auditors that would have otherwise been dismissed had not there been the presence of a former audit partner of the incumbent firm on the audit committee.

My study has limitations, which, if addressed, could provide additional contributions to the audit committee governance. This study includes switches for the year 2007. It is possible the tie effect increases over time. Under this hypothesis, an audit committee member with ties of many years has built up more auditor specific knowledge than a member who recently joined an audit committee. In testing this hypothesis, it would be useful to account for tie duration or to conduct the study using samples drawn from several years.

Audit committee tie influence has potential effects, not addressed in this study, which remain uninvestigated. It seems appropriate to posit ties will influence not only auditor dismissals; but, auditor engagement as well. Larcker and Tayan (2010) suggest researchers study the interlocking directorate with respect to its positive effects on governance. If audit committee auditor ties are associated with engagements, they may have positive, negative or neutral governance effects. Additional research on ties and non-audit services could establish tie effects on economic bonding between clients and their auditors. This additional research could be useful in nations, like Russia, where corporate governance dialogues are ongoing.

\section{REFERENCES}

Bank of Russia. 2014. Corporate governance code. Official Journal of the Bank of Russia. Retrieved March 16, 2017 from http://oecd.org/daf/ca/RussianCodeofCoro rateGovernance2014English.pdf

Blouin, J., B. Grein and B. Rountree. 2007. Analysis of forced auditor change: the case of former Arthur Andersen clients. The Accounting Review. 82: 621-650.

Blue Ribbon Committee (BRC). 1999. Report and recommendations of the Blue Ribbon

Committee on improving the effectiveness of 
corporate audit committees. Business Lawyer 54: 1067-96.

Carcello, J.V., and T.L. Neal. 2003. Audit committee characteristics and auditor dismissals following "new" going-concern reports. The Accounting Review. 78: 95117.

Chen, K.Y., and J. Zhou. 2007. Audit committee, board characteristics, and auditor switch decisions by Andersen's clients. Contemporary Accounting Research. 24:1085-1117.

Chow, C.W. and S.J. Rice. 1982. Qualified audit opinions and auditor switching. The Accounting Review. 57:326-335.Cohen, J., P. Cohen, S. West, and L. Aiken. 2003. Applied Multiple Regression/Correlation Analysis. Malwah, NJ: Lawrence Erlbaum Associates.

Cohen, J., P. Cohen, S. West, and L. Aiken. 2003. Applied Multiple Regression/Correlation Analysis for the Behavioral Sciences. Mahwah, NJ. Lawrence Erlbaum Associates, Publishers.

Courtney, N.P., C.A. Jubb. 2005. Attachments between directors and auditors: do they affect engagement tenure? Ethics and Auditing. Canberra, Australia. Australian National University Press.

Davison, A.G., B.W. Stening, and W.T. Wai. 1984. Auditor concentration and the impact of interlocking directorates. Journal of Accounting Research. 22: 313-317.

Ettredge, M.L., C. Li, and S. Scholz. 2007. Audit fees and auditor dismissals in the Sarbanes-Oxley era. Accounting Horizons. 21: 371-386.

Hennes, K. M., Leone, A. J., \& Miller, B. P. 2013. Determinants and market consequences of auditor dismissals after accounting restatements. The Accounting Review. 89: 1051-1082.

Hogan, C.E. and D.C. Jeter. 1999 Industry specialization by auditors. Auditing a Journal of Practice and Theory. 18:1-17.

Iwasaki, I. 2014. What determines audit independence and expertise in Russia? firm-level evidence. Corporate Ownership and Control. 11: 81-107.

Klein, A. 2002. Economic determinants of audit committee independence. The Accounting Review. 77: 435-452.
Landsman, W., K. K. Nelson and B. Rountree. 2009. Auditor switches in the pre- and post- Enron eras: risk or realignment. The Accounting Review. 84: 531-558.

Larcker, D. F. and B.Tayan. 2010. Director networks: Good for the director, good for the shareholder. Closer Look Series: Topics, issues, and Controversies in Corporate Governance - Graduate School of Business Stanford University.

Lennox, C. S. 2005. Audit quality and executive officer' affiliations with CPA firms. Journal of Accounting and Economics. 39: 201231.

Lennox, C. S. and C. W. Park. 2007. Audit Firm Appointments, Audit Firm Alumni, and Audit Committee Independence. Contemporary Accounting Research. 24: 235-58.

Menon, K. and D.D. Williams. 2004. Former audit partners and abnormal accruals. The Accounting Review. 79:1095-1118.

Mizruchi, M. 1996. What do interlocks do? An analysis, critique, and assessment of research on interlocking directorates. Annual Review of Sociology. 22:271-298.

Moscow Exchange. 2015. Moscow Exchange IPO Guide Retrieved March 16, 2017 from ipoguide.moex.com/eng/section-2-4.html.

Organisation for Economic Cooperation and Development. 2017. Corporate governance in Russia. Retrieved March 16, 2017 from www.oecd.org.russia/corporategovernanc einrussia.htm

Naiker, V. and D.S. Sharma. 2009. Former audit partners on the audit committee and internal control deficiencies. The Accounting Review. 84:559-587.

Schwartz, K.B., and K. Menon. 1985. Auditor switches by failing firms. The Accounting Review. 60:248-261.

Shu, S. Z. 2000. Auditor resignations: Clientele effects and legal liability. Journal of Accounting and Economics. 29:173-702.

Shumway, T. 2001. Forecasting bankruptcy more accurately: A simple hazard model. The Journal of Business. 74: 101-124.

Sucher, P., \& Bychkova, S. 2001. Auditor independence in economies in transition: a study of Russia. European Accounting Review. 10: 817-841. 
Tremblay, M.-S., and Y. Gendron. 2010. Governance prescriptions under trial: On the interplay between the logics of resistance and compliance in audit committees. Critical Perspective on Accounting. 22: 259-272.

United States Government Printing Office. 2002. Public Law 107-204 - Sarbanes Oxley Act of 2002. Retrieved September 26, 2009 from http://www.gpo.gov/fdsys/pkg/PLAW107publ204/html/PLAW-107publ204.htm.

Useem, M. 1984. The Inner Circle. New York, NY, Oxford University Press.

Vafeas, N. 2006. Audit committees, boards and the quality of reported earnings. Contemporary Accounting Research. 22: 1093-1122.

\section{ABOUT THE AUTHOR}

Genevieve Scalan, email: Genevieve.Scalan@tamuk.edu

Dr. Genevieve Scalan is an Assistant Professor at Texas A \& M University - Kingsville in Kingsville, Texas, USA. She earned her PhD in accounting at the University of Arkansas. 